\title{
Litomosoides silvai (Nematoda: Onchocercidae) parasitizing Akodon montensis (Rodentia: Cricetidae) in the southern region of Brazil
}

\author{
Litomosoides silvai (Nematoda: Onchocercidae) parasitando Akodon montensis (Rodentia: Cricetidae) \\ na região Sul do Brasil
}

Lucas Trevisan Gressler ${ }^{1}$; Felipe da Silva Krawczak ${ }^{2,3}$; Marcelo Knoff'; Silvia Gonzalez Monteiro ${ }^{1 *}$;

Marcelo Bahia Labruna'; Lina de Campos Binder ${ }^{2}$; Caroline Sobotyk de Oliveira ${ }^{5}$; Juliana Notarnicola ${ }^{6}$

\begin{abstract}
${ }^{1}$ Laboratório de Parasitologia Veterinária, Departamento de Microbiologia e Parasitologia, Universidade Federal de Santa Maria UFSM, Santa Maria, RS, Brasil

${ }^{2}$ Laboratório de Doenças Parasitárias, Departamento de Medicina Veterinária Preventiva e Saúde Animal, Faculdade de Medicina Veterinária e Zootecnia, Universidade de São Paulo - USP, São Paulo, SP, Brasil

${ }^{3}$ Laboratório de Doenças Parasitárias, Departamento de Medicina Veterinária Preventiva, Escola de Veterinária e Zootecnia, Universidade Federal de Goiás - UFG, Goiânia, GO, Brasil

${ }^{4}$ Laboratório de Helmintos Parasitos de Vertebrados, Instituto Oswaldo Cruz - FIOCRUZ, Rio de Janeiro, RJ, Brasil

${ }^{5}$ Laboratório de Doenças Parasitárias, Departamento de Medicina Veterinária Preventiva, Universidade Federal de Santa Maria UFSM, Santa Maria, RS, Brasil

${ }^{6}$ Instituto de Biología Subtropical - IBS, Consejo Nacional de Investigaciones Científicas y Técnicas - CONICET, Puerto Iguazú, Misiones, Argentina
\end{abstract}

Received June 27, 2017

Accepted September 15, 2017

\begin{abstract}
In the present study, Litomosoides silvai parasitizing Akodon montensis in the southern region of Brazil is reported for the first time. New morphological information is provided for some structures of this nematode species, such as a flattened cephalic extremity, presence of two dorsal cephalic papillae, female tail with a constriction at its tip, "s" shaped vagina, spicules characteristic of the carinii species group and microfilaria tail constricted at the tip. This nematode was found parasitizing the thoracic cavity with a prevalence of $10 \%(2 / 20)$, mean intensity of $4(6 / 2)$, mean abundance of $0.4(8 / 20)$ and range of infection of 2-6 specimens per host, in southern Brazil. This occurrence of L. silvai in A. montensis is a new geographical record for southern Brazil, in the Upper Paraná Atlantic Forest ecoregion of the northwestern region of Rio Grande do Sul, which is part of the Atlantic Forest biome.
\end{abstract}

Keywords: Filarioid, Atlantic Forest biome, nematode, rodent, Rio Grande do Sul.

\section{Resumo}

No presente estudo é relatado pela primeira vez Litomosoides silvai parasitando Akodon montensis coletados na região Sul do Brasil. Foram fornecidas novas informaçôes morfológicas para algumas estruturas desta espécie de nematódeo, tais como extremidade cefálica achatada, a presença de duas papilas cefálicas dorsais, cauda das fêmeas com uma constrição na ponta da cauda, vagina em forma de "s", espículas de característica do grupo de espécies de carinii e cauda da microfilária com constrição na ponta. Este nematódeo parasitava a cavidade torácica com uma prevalência de $10 \%(2 / 20)$, intensidade média de 4 (8/2) e abundância média de 0,4 (8/20), e intervalo de infecção de 2-6 espécimes por hospedeiro no Sul do Brasil. A ocorrência de L. silvai em A. montensis é um novo registro geográfico, no sul do Brasil, a noroeste do estado do Rio Grande do Sul, na ecorregião da Mata Atlântica do Alto Paraná, parte do bioma da Mata Atlântica.

Palavras-chave: Filarideo, bioma Mata Atlântica, nematoda, roedor, Rio Grande do Sul.

${ }^{*}$ Corresponding author: Sílvia Gonzalez Monteiro. Laboratório de Parasitologia Veterinária, Departamento de Microbiologia e Parasitologia, Universidade Federal de Santa Maria - UFSM, Prédio 20, sala 4200, CEP 97105-900, Santa Maria, RS, Brasil. e-mail: sgmonteiro@uol.com.br 


\section{Introduction}

Turvo State Park (Parque Estadual do Turvo, PST) is a natural reserve located in the northwest of the state of Rio Grande do Sul, southern Brazil, comprising an area of approximately 17,491 hectares. The park is covered almost entirely by subtropical broadleaf or broadleaf deciduous forest. The mammal fauna of the park consists of carnivores such as Galictis sp., Cerdocyon thous, Nasua nasua, Procyon cancrivorus, Eira barbara, wild cats, herbivorous like deer and tapirs, some species of lagomorphs, primates, didelphimorphia, and xenarthrans, many species of chiropterans and as well as numerous rodents (KASPER et al., 2007; MELO et al., 2011).

One of the genera of Cricetidae rodents that is well represented in Brazil is Akodon Meyen, 1833, with 10 species recorded in this country (SILVEIRA et al., 2013). Among these, Akodon montensis Thomas, 1913 is the only species of this genus found in this reserve (MELO et al., 2011). This species occurs in Paraguay, northern Argentina and southeastern to southern Brazil, including the states of Minas Gerais, Rio de Janeiro, São Paulo, Paraná, Santa Catarina, and Rio Grande do Sul (MUSSER \& CARLETON, 2005).

Filarioids of the genus Litomosoides Chandler, 1931, are parasites of the abdominal and thoracic cavities of bats, marsupials and many rodents. Currently, this genus is represented by 43 known species (NOTARNICOLA et al., 2012; NOTARNICOLA \& de la SANCHA, 2015; OVIEDO et al., 2016). In Brazil, species of Litomosoides have been found parasitizing marsupials (BAIN et al., 1980; MULLER, 1980), bats (LINS DE ALMEIDA, 1936 apud NOTARNICOLA et al., 2010; REGO, 1961; GUERRERO et al., 2002; BAIN et al., 2003) and rodents (TRAVASSOS, 1919 apud PADILHA \& FARIA, 1977; PADILHA \& FARIA, 1977; BAIN et al., 1989; MORAES-NETO et al., 1997; SIMÓES et al., 2012). Two species, Litomosoides silvai (PADILHA \& FARIA, 1977) and Litomosoides chagasfilhoi (MORAES-NETO et al., 1997) have been recorded in the rodent Akodon cursor Winge, 1887, in Itaguaí and Rio Bonito, in the Atlantic Forest region of the state of Rio de Janeiro (PADILHA \& FARIA, 1977; MORAES-NETO et al., 1996, 1997; MORAES-NETO \& LANFREDI 1997; SIMÓES et al., 2011, 2012).

The aim of the present study was to report on $L$. silvai parasitizing A. montensis in the Turvo State Park, state of Rio Grande do Sul, Brazil, which is in the Upper Paraná Atlantic Forest ecoregion, part of Atlantic Forest biome. Furthermore, this study provides new morphological data for some structures, such as the cephalic extremity, tail and vagina, spicules and microfilariae tail; and it presents parasitological indices (prevalence, mean intensity and mean abundance) and data on range and infection site.

\section{Materials and Methods}

During a survey carried out to study tick-borne diseases (KRAWCZAK, 2016), 164 specimens of small mammals were caught: 117 Akodon montensis, 13 Brucepattersonius iheringi, 1 Cryptonanus guahybae, 7 Didelphis aurita, 1 Euryoryzomys russatus, 9 Oligoryzomys nigripes, 7 Oxymycterus judex, 4 Sooretamys angouya and 5 Thaptomys nigrita. They were caught in the Turvo State Park (latitude $27^{\circ} 00^{\prime} \mathrm{S}$ to $27^{\circ} 20^{\prime} \mathrm{S}$; longitude $53^{\circ} 40^{\prime} \mathrm{W}$ to $\left.54^{\circ} 10^{\prime} \mathrm{W}\right)$, in the northwest of the state of Rio Grande do Sul, Brazil, between June 2013 and January 2014. However, only some of the rodents, which died due to the procedures for anesthesia and blood collection, were used in the present study: 20 specimens of Akodon montensis Thomas, 1913; two Brucepattersonius iheringi Thomas, 1896; one Oxymycterus judex Thomas, 1909; and one Oligoryzomys nigripes Olfers, 1818. Some other rodents that died were preserved in absolute ethanol until arrival at the Parasitic Diseases Laboratory of the School of Veterinary Medicine and Animal Science, Universidade de São Paulo (USP). These were then analyzed for tick presence and were identified in accordance with Bonvicino et al. (2008) and Melo et al. (2011). These animals were deposited in the Rodent Collection of the "Luiz de Queiroz" Higher Agriculture School, USP, state of São Paulo, Brazil.

The animals were caught using a total of 80 live traps ( 75 Sherman and five Tomahawk) baited with bacon, banana, apple and peanut butter. These were set up for four consecutive nights during each field campaign. Additionally, three pitfall stationary traps each consisting of five buckets of $42.5 \mathrm{~cm}$ in diameter and $60 \mathrm{~cm}$ in height, which were connected using a plastic fence (at least $30 \mathrm{~m}$ long and $50 \mathrm{~cm}$ high), were set up for the same period. The animals thus trapped were then anaesthetized using ketamine and xylazine.

Adult nematode specimens were recovered from the thoracic cavity of $A$. montensis, stored in Railliet \& Henry liquid, and were sent to the Veterinary Parasitology Laboratory, Universidade Federal de Santa Maria, state of Rio Grande do Sul, Brazil, for identification. To study their morphological characteristics, they were then cleared in lactophenol, temporarily mounted, examined under a bright-field microscope (Olympus BX-51) and photographed using a Zeiss Axiophot. Microfilariae from the uterus of one fixed female were dissected and examined. Illustrations were made with the aid of a drawing tube. Measurements are given in micrometers unless otherwise stated. The parasite terms used are in accordance with Bush et al. (1997).

Nematode specimens were deposited in the Helminth Collection of the Museum of La Plata (MLP-he). Moreover, specimens of L. silvai parasitizing $A$. cursor, from Rio Bonito, state of Rio de Janeiro (MORAES-NETO et al., 1996) deposited in the Oswaldo Cruz Institute Helminthological Collection (CHIOC) under number 33518 (one female and one male) were studied to improve the diagnosis.

This study was approved by the Ethics Committee on Animal Use of the School of Veterinary Medicine and Animal Science, USP, under protocol number 2908/2013; by the Chico Mendes Institute for Biodiversity Conservation (ICMBio), under license number SISBIO 38502-1; and by the State Environmental Department of Rio Grande do Sul (SEMA, RS).

\section{Results}

Three female filarioid specimens, two anterior extremities and three posterior extremities were recovered from the thoracic cavity of two specimens of $A$. montensis. Morphometric data on the female and microfilarial specimens are showed in Table 1. The species identification was aided through studying male and female specimens deposited in CHIOC (number 33518). 
Table 1. Compared measurements of females from Litomosoides silvai reported in the literature and the present study.

\begin{tabular}{lccc}
\hline \multicolumn{1}{c}{ Host species } & Akodon cursor & Akodon cursor & Akodon montensis \\
\hline Reference & Padilha \& Faria (1977) & Moraes-Neto et al. (1996) & Present study \\
Locality, Country & Serra do Caçador, Itaguaí, RJ. & Catimbau Grande, Rio Bonito, RJ. & Parque Estadual do Turvo, Derrubadas, RS. \\
Localization & Thoracic cavity & Thoracic cavity & Thoracic cavity \\
Females & $(\mathrm{n}=10)$ & $(\mathrm{n}=10)$ & $(\mathrm{n}=6)$ \\
Body length (mm) & $46-64$ & $48.9-89$ & $60.88-82.46$ \\
Body width & $250-290$ & $220-363$ & $211-230$ \\
Buccal capsule length & $16-25$ & $17-25$ & $16-22$ \\
Esophagus length & $440-750$ & $491-659$ & $480-1040$ \\
Tail lengh & $440-800$ & $267-450$ & $380-480$ \\
Vulva to apex & $1000-1650$ & $1011-3159$ & $1340-2000$ \\
Microfilariae length & - & $68-77^{*}$ & $87-91^{*}$ \\
\hline
\end{tabular}

Measurements are in micrometers (unless otherwise indicated); *Uterine microfilariae.

\section{Litomosoides silvai Padilha and Faria, 1977}

(Figures 1-11)

Diagnosis: Adult worms small, males four times smaller than females. Cephalic extremity flattened. In apical view, 4 labial papillae distributed in a stretched dorsoventral rectangle; 2 dorsal cephalic papillae. Buccal capsule slender; anterior segment transparent and posterior chitinous portion with irregular external walls; buccal cavity with 2 short enlargements near the base. Female tail slender, with a constriction at tip of tail. Esophagus muscular, becoming slightly glandular in the posterior portion. Vulva posterior to the esophagus-intestine junction. Vagina "s" shaped; vagina perpendicular to the axis of the vulva with a flattened lumen consisting of a simple " $\mathrm{s}$ " shaped tube surrounded by muscular walls. Male tail slender; left spicule with handle longer than blade; blade consisting of a membranous ala that converts into a filament; right spicule is a twisted conduit with a heel that is not strongly cuticularized. Microfilariae slender, with sheath closely applied to the body; nuclei not extending to the tip of tail; tail becomes constricted.

\section{Taxonomic summary}

Host: Akodon montensis Thomas, 1913.

Locality: Turvo State Park, state of Rio Grande do Sul, Brazil.

Infection site: thoracic cavity.

Parasitological indices: prevalence $(\mathrm{P})=10 \%(2 / 20)$, mean intensity $(\mathrm{MI})=4(6 / 2)$, mean abundance $(\mathrm{MA})=0.4(8 / 20)$ and range of infection of 2-6 specimens per host.

Specimen deposition numbers: MLP-he 7204; MLP-he 7205.

\section{Remarks}

The specimens found in $A$. montensis correspond to the species $L$. silvai and are in accordance with the morphology and morphometrical characteristics given by Padilha $\&$ Faria (1977) and Moraes-Neto et al. (1996). The identification was confirmed by the shape of the buccal capsule, flattened anterior extremity, vulva located posteriorly to the esophagus-intestine

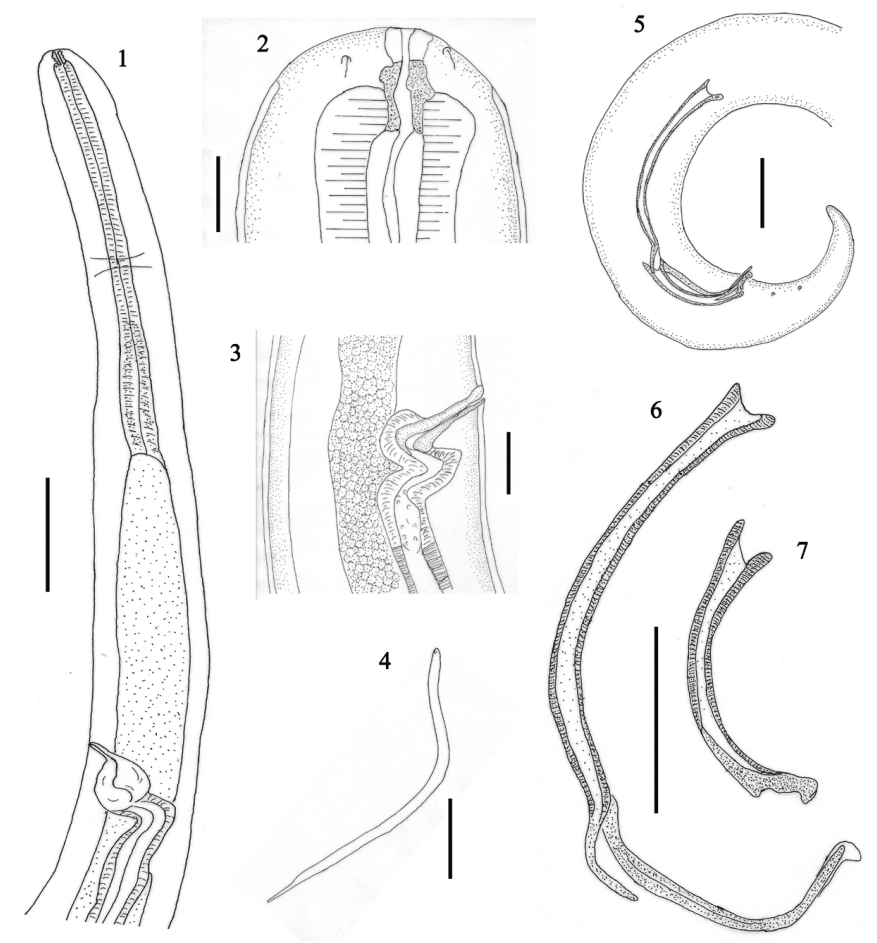

Figure 1-7. 1-4. Female specimens of Litomosoides silvai parasitizing Akodon montensis from Turvo State Park, state of Rio Grande do Sul. 1. Anterior region of female, lateral view. 2. Anterior extremity, lateral view. 3. Detail of the vulva, lateral view. 4. Uterine microfilaria. 5-7. Male specimen of $L$. silvai parasitizing A. cursor, from Rio Bonito, state of Rio de Janeiro, CHIOC 33518. 5. Posterior extremity showing the spicules and the cloaca, lateral view. 6. Detail of the left spicule, lateral view. 7. Detail of the right spicule, lateral view. Scale bars: $1=200 \mu \mathrm{m} ; 2$ and $4=20 \mu \mathrm{m} ; 3,5-7=50 \mu \mathrm{m}$.

junction, non-globular shape of the vulva, tail tip with a constriction, shape of the spicules corresponding to the carinii species group, and constricted tail tip of the microfilariae. In the present study, female specimens were compared with previous specimens deposited in CHIOC, which confirmed the identity of the species. 

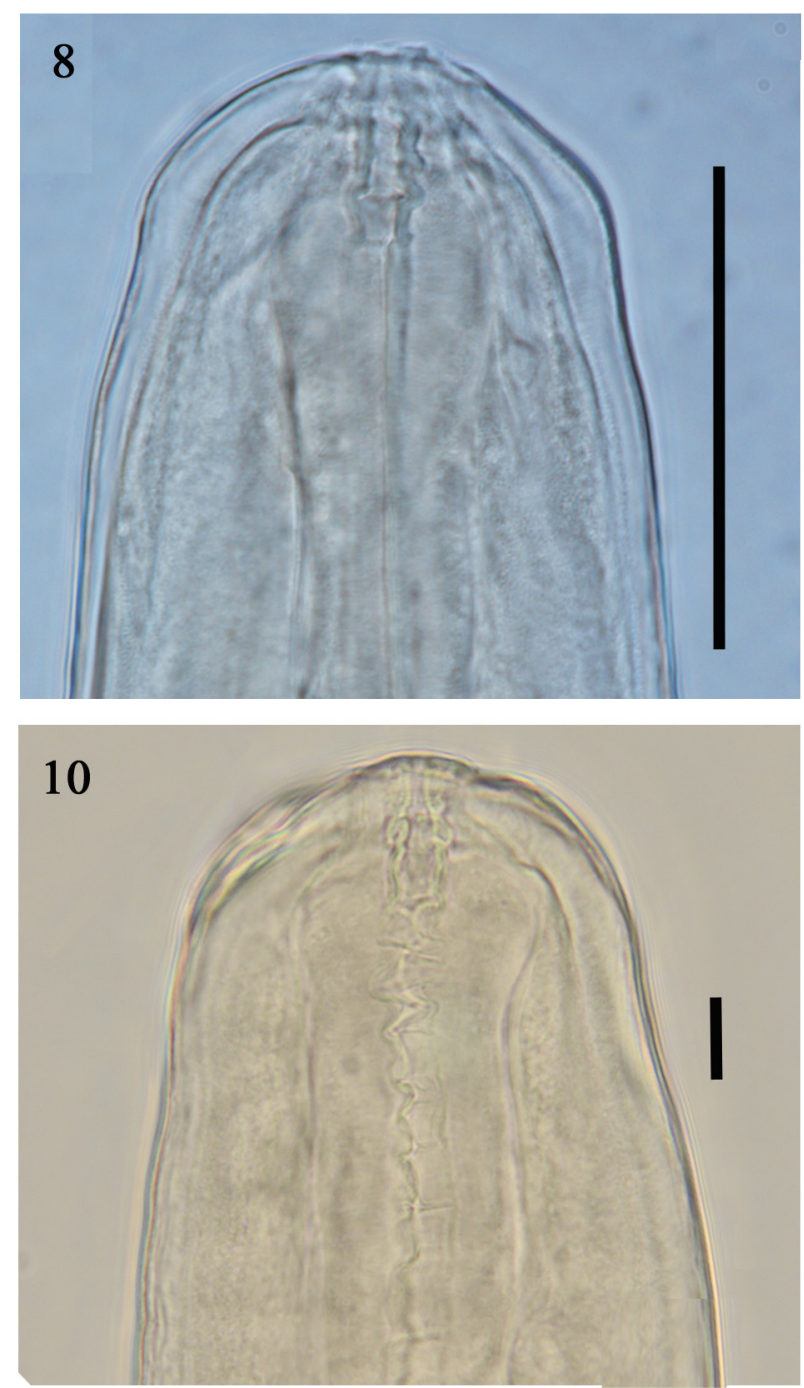
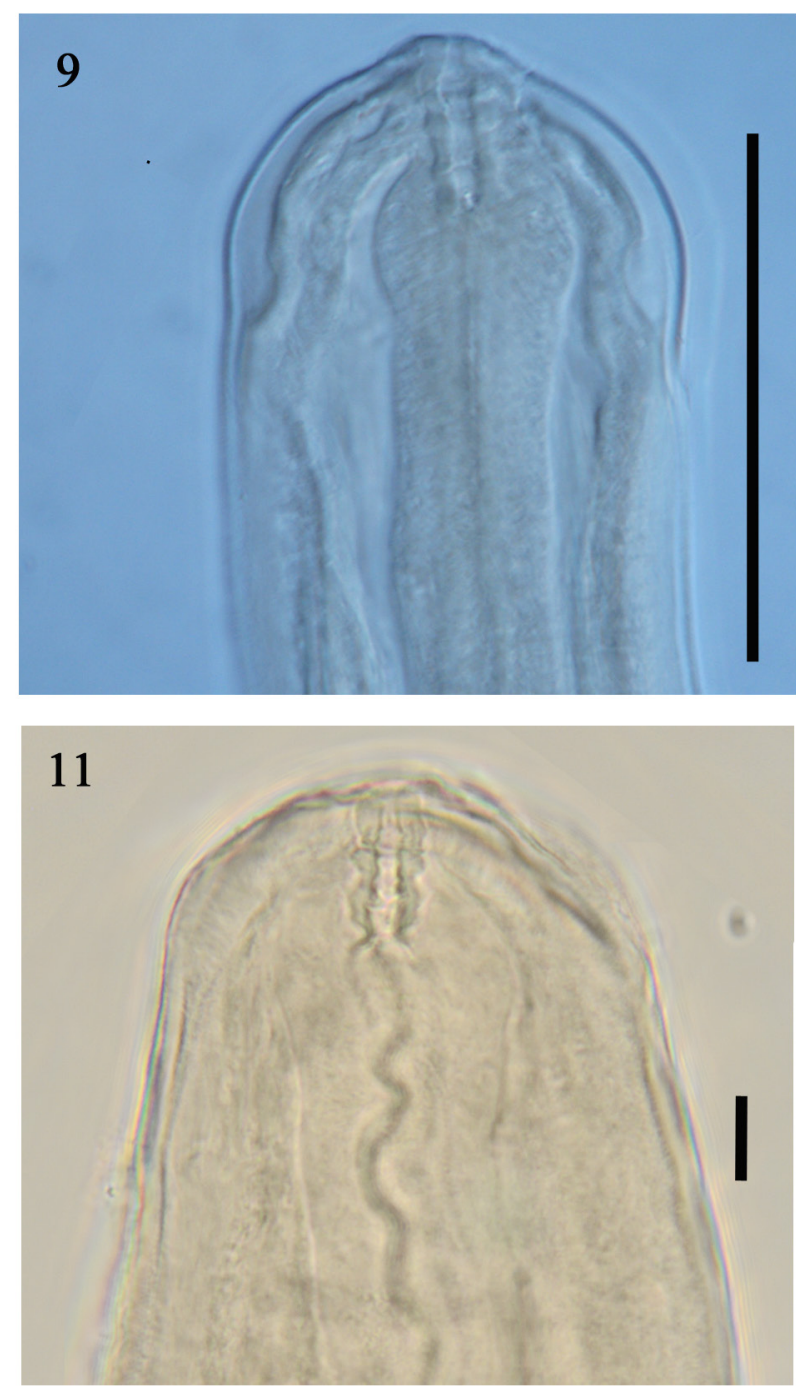

Figure 8-11. Detail of anterior extremities of Litomosoides silvai. 8-9. Female and male specimens, respectively, of $L$. silvai parasitizing Akodon cursor, from Rio Bonito, state of Rio de Janeiro, CHIOC 33518. 10-11. Female specimen of L. silvai parasitizing A. montensis from Turvo State Park, state of Rio Grande do Sul. Scale bars: 8-9 = $25 \mu \mathrm{m}$; 10-11: $10 \mu \mathrm{m}$.

\section{Discussion}

Litomosoides silvai was originally described by Padilha \& Faria (1977), as a parasite of $A$. cursor. Later on, Moraes-Neto et al. (1996) redescribed the species including new morphological data and scanning electron microphotographs. These authors showed the distribution of the head papillae, the rugose area, the tip of the tail and the structure of the cuticle at the vulva. However, the position of the head papillae was not stated.

Here, four labial papillae distributed in a stretched dorsoventral rectangle and two dorsal cephalic papillae were observed; amphids were located ventrally in relation to the cephalic papillae. Additionally, the vulva was " $\mathrm{s}$ " shaped and differed from the globular shape of other Litomosoides species (NOTARNICOLA et al., 2000; OVIEDO et al., 2016).

Recently, Simóes et al. $(2011,2012)$ reported the presence of L. silvai parasitizing the sympatric rodents $A$. cursor and $A$. montensis in Teresópolis, state of Rio de Janeiro (RJ). All previous reports of L. silvai are from the Atlantic Forest ecoregion, in the state of Rio de Janeiro. Therefore, in the present study, the occurrence of L. silvai in A. montensis in southern Brazil is a new geographical record, in the Upper Paraná Atlantic Forest ecoregion of the northwest of the state of Rio Grande do Sul, which is part of the Atlantic Forest biome.

According to Moraes-Neto \& Lanfredi (1997), L. silvai parasitizing A. cursor in Rio Bonito, RJ (Serra do Mar Coastal Atlantic Forest ecoregion), presented $\mathrm{P}=20.7 \%(12 / 58), \mathrm{MI}=18.6(223 / 12)$ and $\mathrm{MA}=3.8(223 / 58)$; while Simóes et al. (2011) reported $\mathrm{P}=12 \%$, $\mathrm{MI}=2$ and $\mathrm{MA}=0.2$, in Teresópolis, RJ, which is a nearby locality. Moreover, these last authors also found $L$. silvai parasitizing the sympatric rodent $A$. montensis ( $\mathrm{P}=2 \%, \mathrm{MI}=26$ and $\mathrm{MA}=0.5)$. The results from the present study show intermediate values that may be related to a different ecoregion or that may show that environmental factors are involved. Interestingly, in Rio Bonito A. cursor was also found to be parasitized with L. chagasfilhoi, with a prevalence of $12 \%$, and both species of filarioids were 
concurrent in 4 out of the 58 hosts sampled (MORAES-NETO \& LANFREDI, 1997).

It seems that $L$. silvai always is located in the thoracic cavity when it parasitizes $A$. cursor or $A$. montensis, while L. chagasfilho $i$ is located in the abdominal cavity. Both species of filarioid are present in Rio Bonito, while only L. silvai is present in the other localities (Teresópolis and Turvo State Park). Thus, L. silvai is present in both Akodon species, but because of the different southern distribution of their hosts, the filarioid only follows $A$. montensis, which is the only species of this genus that has been trapped in the study area (MELO et al., 2011). It is interesting to note that among more than 236 specimens of $A$. montensis that were sampled by one of the present authors (JN, unpublished data) in different localities in Misiones province (Argentina), which is close to Turvo State Park, no filarioid specimens were detected.

\section{Acknowledgements}

This work was supported financially by the Fundação de Amparo a Pesquisa do Estado de Sáo Paulo (FAPESP) (processes no 2012/21915-4 and 2016/07241-1), Conselho Nacional de Desenvolvimento Científico e Tecnológico (CNPq) and Coordenadoria de Apoio a Pesquisa e Desenvolvimento (CAPES), and was authorized by the Chico Mendes Institute for Biodiversity Conservation (authorization SISBIO 38502-1) and the Ethics Committee on Animal Research of the School of Veterinary Medicine of the University of São Paulo (protocol 2908/2013).

\section{References}

Bain O, Guerrero R, Rodriguez B, Babayan S, Jouvenet N. Examination of type material of two species of Litomosoides (Filarioidea: Onchocercidae), parasites from bats; taxonomic consequences. Parasite 2003; 10(3): 211218. PMid:14535160. http://dx.doi.org/10.1051/parasite/2003103211.

Bain O, Petit G, Berteaux S. Description de deux nouvelles Filaires du genre Litomosoides et de leurs stades infestants. Ann Parasitol Hum Comp 1980; 55(2): 225-237. PMid:7458160. http://dx.doi.org/10.1051/ parasite/1980552225.

Bain O, Petit G, Diagne M. Étude de quelques Litomosoides parasites de rongeurs; coséquences taxonomiques. Ann Parasitol Hum Comp 1989; 64(4): 268-289. PMid:2817694. http://dx.doi.org/10.1051/ parasite/1989644268.

Bonvicino CR, Oliveira JA, D’Andrea PS. Guia dos roedores do Brasil, com chaves para gêneros baseadas em caracteres externos. Duque de Caxias: Centro Pan-Americano de Febre Aftosa; 2008.

Bush AO, Lafferty KD, Lotz JM, Shostak AW. Parasitology meets ecology on its own terms: Margolis et al. revisited. J Parasitol 1997; 83(4): 575-583. PMid:9267395. http://dx.doi.org/10.2307/3284227.

Guerrero R, Martin C, Gardner SL, Bain O. New and known species of Litomosoides (Nematoda: Filarioidea): Important adult and larval characters and taxonomic changes. Comp Parasitol 2002; 69(2): 177195. http://dx.doi.org/10.1654/1525-2647(2002)069[0177:NAKS $\mathrm{OL}] 2.0 . \mathrm{CO} ; 2$.

Kasper CB, Mazim FD, Soares JBG, Oliveira TG, Fabián ME. Composiçáo e abundância relativa dos mamíferos de médio e grande porte no Parque Estadual do Turvo, Rio Grande do Sul, Brasil. Rev Bras Zool 2007; 24(4): 1087-1100. http://dx.doi.org/10.1590/S010181752007000400028 .

Krawczak FS. Pesquisa de infecção por riquétsias do grupo da febre maculosa em cães, pequenos mamíferos e carrapatos em área endêmica e não endêmica nos biomas Pampa e Mata Atlantica no estado do Rio Grande do Sul. [tese]. São Paulo: Universidade de São Paulo; 2016.

Melo GL, Sponchiado J, Machado AF, Cáceres NC. Small-mammal community structure in a South American deciduous Atlantic Forest. Community Ecol 2011; 12(1): 58-66. http://dx.doi.org/10.1556/ ComEc.12.2011.1.8.

Moraes-Neto AHA, Lanfredi RM, Souza W. Emended description of Litomosoides silvai (Nematoda: Filarioidea) of Akodon cursor (Rodentia: Muridade). J Parasitol 1996; 82(6): 988-991. PMid:8973410. http:// dx.doi.org/10.2307/3284210.

Moraes-Neto AHA, Lanfredi RM, Souza W. Litomosoides chagasfilhoi sp. nov. (Nematoda: Filarioidea) parasitizing the abdominal cavity of Akodon cursor (Winge, 1887) (Rodentia: Muridae) from Brazil. Parasitol Res 1997; 83(2): 137-143. PMid:9039695. http://dx.doi.org/10.1007/ s004360050223.

Moraes-Neto AHA, Lanfredi RM. Prevalence of two species of Litomosoides (Nematoda: Filarioidea) parasites of Akodon cursor (Rodentia: Muridae) from southeastern Brazil. Rev Bras Biol 1997; 57(4): 579-582. PMid:9440357.

Muller R. Litomosoides barretti n. sp. from the ashy opossum in Brazil (Nematoda, Filarioidea). Rev Bras Biol 1980; 40(1): 81-83.

Musser GM, Carleton MD. Superfamily Muroidea. In: Wilson DE, Reeder DM, editors. Mammal species of the world: A taxonomic and geographic reference. 3 rd ed. Baltimore: Johns Hopkins University Press; 2005. p. 894-1531.

Notarnicola J, Bain O, Navone GT. Two new species of Litomosoides (Nematoda: Filarioidea) in sigmodontines (Rodentia: Muridae) from Rio de La Plata marshland, Argentina. J Parasitol 2000; 86(6): 1318-1325. PMid:11191910. http://dx.doi.org/10.1645/00223395(2000)086[1318:TNSOLN]2.0.CO;2.

Notarnicola J, de la Sancha NU. Description of Litomosoides ysoguazu n. sp. (Nematoda, Onchocercidae) a parasite of the tuft-toed rice rat Sooretamys angouya (Fisher) (Rodentia, Cricetidae), and a first record of L. esslingeri Bain, Petit \& Berteaux, 1989 in Paraguay. Syst Parasitol 2015; 91(2): 175-184. PMid:25962465. http://dx.doi.org/10.1007/ s11230-015-9563-2.

Notarnicola J, Jiménez-Ruiz FA, Gardner SL. A new species of Molinema (Nematoda: Onchocercidae) in bolivian rodents and emended description of Litomosoides esslingeri Bain, Petit, and Diagne, 1989. J Parasitol 2012; 98(6): 1200-1208. PMid:22680839. http://dx.doi. org/10.1645/GE-3059.1.

Notarnicola J, Jiménez-Ruiz FA, Gardner SL. Litomosoides (Nemata: Filarioidea) of Bats from Bolivia with Records for Three Known Species and the Description of a New Species. J Parasitol 2010; 96(4): 775-782. PMid:20738202. http://dx.doi.org/10.1645/GE-2371.1.

Oviedo MC, Notarnicola J, Miotti MD, Claps LE. Emended description of Litomosoides molossi (Nematoda: Onchocercidae) and first records of Litomosoides species parasitizing argentinean bats. J Parasitol 2016; 102(4): 440-450. PMid:27098753. http://dx.doi.org/10.1645/15-776. 
Padilha TN, Faria MJ. Litomosoides silvai n. sp. proveniente de rato do mato, Akodon arviculoides (Wagner) (Nematoda, Filarioidea). Rev Bras Biol 1977; 37(3): 535-537.

Rego AA. Sobre algumas espécies do gênero Litomosoides Chandler, 1931 (Nematoda: Filarioidea). Mem Inst Oswaldo Cruz 1961; 59(1): 1-9. PMid:13740379. http://dx.doi.org/10.1590/S0074-02761961000100001.

Silveira F, Sbalqueiro IJ, Monteiro-Filho ELA. Identification of the brazilian species of Akodon (Rodentia: Cricetidae: Sigmodontinae) through the microstructure of the hair. Biota Neotrop 2013; 13(1): 339-345. http://dx.doi.org/10.1590/S1676-06032013000100033.
Simões RO, Maldonado-Júnior A, Luque JL. Helminth communities in three sympatric rodents from Brazilian Atlantic Forest: contrasting biomass and numerical abundance. Braz J Biol 2012; 72(4): 909-914. PMid:23295521. http://dx.doi.org/10.1590/S1519-69842012000500018.

Simôes RO, Souza JGR, Maldonado-Júnior A, Luque JL. Variation in the helminth community structure of three sympatric sigmodontine rodents from the coastal Atlantic Forest of Rio de Janeiro, Brazil. $J$ Helminthol 2011; 85(2): 171-178. PMid:20701831. http://dx.doi. org/10.1017/S0022149X10000398. 